\title{
The Relationship between Awareness of HIV and AIDS Workplace Policy and Consultation on HIV and AIDS Policy Development among Staff of Moi University, Kenya
}

Naftal Michira Nyang'ara: School of Education, Laikipia University, Nyahururu- Kenya, Department of Psychology, Laikipia University, Kenya.

\begin{abstract}
The unprecedented effect of HIV and AIDS in Africa cannot be over-emphasized as it takes its toll mainly on the active age population of 15-49 years. This age group is the main workforce of any nation and, unfortunately, the most vulnerable to infection of HIV. There has been growing concern about the devastating impact of HIV and AIDS in many workplaces. In response, many universities have developed university specific HIV and AIDS policies for impact mitigation in the workplace. Moi University is a public institution with a large workforce hence targeted in the current study. Realizing the negative impact that HIV and AIDS has on workplaces and the importance of having an HIV and AIDS workplace policy, this study sought to determine the relationship between awareness of HIV and AIDS workplace policy and consultation on HIV and AIDS policy development among staff of Moi University. The study, whose main concern was about Moi University HIV and AIDS workplace policy, targeted teaching staff, non-teaching staff and senior management. To achieve this objective, the study used ex-post facto research design and stratified sampling technique in the selection of the study sample. A study sample made up of 330 participants was used for the study. The study utilized both qualitative and quantitative methods in data collection. These included Workplace Testing Questionnaire, document analysis and semi-structured interviews. Primary data was collected by use of selfadministered questionnaires and interview schedules, while secondary data was collected from libraries. The study used the Statistical Package for Social Sciences (SPSS v 22.0) program to analyze the data collected. Qualitative data was analyzed thematically through coding. Both descriptive and inferential statistics were used. The descriptive statistics included frequencies and means. Correlation analysis was used to test hypotheses (to test the relationship between the independent and dependent variables). The findings revealed that Moi University had an HIV and AIDS workplace policy. It also emerged that lack of consultation on HIV policy development, was an impediment to successful implementation of the policy. The study concluded that HIV and AIDS workplace policy is a vital document in HIV and AIDS impact mitigation and, therefore, requires serious consultation among all employees of Moi University for purposes of ownership by every employee. Following this, the study recommended that consultation of all of all employees about HIV and AIDS workplace policy development be undertaken and worker's views and opinion be considered when developing an HIV and AIDS workplace policy. The study is, therefore, expected to be of great significance to universities in addressing some of the HIV and AIDS workplace policy related implementation challenges.
\end{abstract}

Key words: Awareness of HIV, AIDS workplace policy.

\section{Introduction}

An HIV and AIDS workplace policy is a written document that sets out the organization's position and practices as they relate to HIV and AIDS (International Labour Office, 2004). It provides the framework for action to reduce the spread of HIV and AIDS and manage its impact on the workplace. It 
guides managers and supervisors on how to manage HIV and AIDS in a consistent manner and informs employees about their responsibilities, rights and expected behaviour (International Labour Organization (ILO), 2002). It further sets standards for communication about HIV and AIDS and lets employees know what assistance is available to them.

HIV and AIDS workplace policy outlines how the organization is going to manage HIV and AIDS It also outlines principles of a workplace programme and how the workplace programme will be transformed into practice to realize the policy objectives. The HIV and AIDS programme is an actionorientated plan to prevent new HIV infections, provide care and support to all employees and to manage the impact on the organisation (International Labour Organization (ILO), 2001). A comprehensive HIV and AIDS workplace programme must include several key elements. Among the most common elements are: HIV and AIDS impact assessment of the organisation; HIV and AIDS awareness programmes; voluntary counselling and testing programmes; HIV and AIDS education and training; condom distribution; provision of anti-retroviral therapy, and referral to relevant service providers.

The process of developing an HIV and AIDS workplace policy is as important as the policy itself (International Labour Office, 2004). These steps should be integrated into a comprehensive policy that is planned, implemented and monitored in a sustained and ongoing manner (International Labour Organization (ILO), 2001). It is necessary that all members of the workplace acknowledge that HIV and AIDS is an issue that affects the workplace and requires a response. It is better to be proactive and to develop a workplace policy rather that to wait for a potential crisis. The involvement of senior management gives legitimacy and credibility to the policy development process (Phakathi, 2006). A useful strategy is to find champions for the process, people who are passionate about the process and who will implement it.

All employees need to feel part of the process and have the opportunity to give their input. The draft of the policy should be distributed to everyone in the organization and the content and implications for the workplace need to be explained. After such consultation, the organization can formally adopt the reviewed policy. According to Oti-Boateng, Owusu-Daaku, and Yeboah (2004) although awareness of HIV and AIDS is very high among students and staff in Kwameh Nkrumah University of Science and Technology (KNUST), there is some level of ignorance surrounding the disease in totality, particularly among people who are not health professionals. There is also a lot of secrecy, silence, denial and fear of stigmatization and discrimination. To compound the problem, there is no reliable data on the level of infection among students and staff. Information on AIDSrelated deaths among academic and support staff is also patchy, partly because it is very seldom stated that a particular death was due to AIDS. This is also a manifestation of the silence and denial that tend to cloud the disease. As part of its core mandate of teaching, research and service to the community, KNUST is also engaged in activities that promote dissemination and preservation of knowledge regarding HIV transmission, and its impact on the university, the individual, the family and the community. In 2000, KNUST was the first University in Africa to establish the Health and Nutrition Coordinating Centre with the main objective of educating through counselling and the mainstreaming of HIV and AIDS into its curriculum, offering nutrition advice to People living with HIV and AIDS (PLWHA), develop a draft institutional policy and also providing fora for dispassionately disseminating information and dealing with the disease (Oti-Boateng et al., 2004). Teaching staff are central pillars in the university education system and their survival and wellbeing is essential for the sustainability of the system. However, HIV and AIDS have shown a potential to erode the gains made in education over the last few decades. Teaching staff are confronted with the impact of HIV and AIDS in many countries in Africa. The challenges teachers face in sub-Saharan Africa include an increasing workload due to absenteeism, sick leave and deaths of colleagues, responsibility for the care of sick relatives and providing assistance to infected and affected pupils (Education International, 2006). In some countries, a tenfold increase in teacher mortality and absenteeism due to HIV and AIDS has severely reduced both teaching time and quality. Permanent or temporary absenteeism of one teacher can have strong repercussions on up to 100 children (UNESCO, 2005). Carr-Hill, Kataboro, and Katahoire (2000) report that teachers are expected to attend to sick relatives in critical conditions and this can take their time from school

Studies

Vol. 2, No.2, pp. 115-120 Funding: This study received no specific financial support.

Article History:
Received: 8 May 2019

Revised: 12 June 2019

Accepted: 16 July 2019

Published: 29 August 2019

(C) 2019 by the authors; licensee Academic Publishing Group 
activities. HIV and AIDS has led to pupils dropping out of school, in their study on AIDS, gender and school drop-out in Rusinga Island, Kenya, found out that school drop-out occurred for both gender because there was no money left to sustain them in school. This could be due to the fact that scarce economic resources may be spent on medical treatment and as such, children may be taken out of school in order to save money for treatment.

\section{Theoretical Framework}

The study was informed by the E-V-R (Environment, value and Resources) congruence model.The model theory was developed by Thompson, Lees, and Alvy (2000) HIV and AIDS workplace policy provides windows of opportunity that can be tapped in impact mitigation. Policy development, then, is a pattern of behaviour, a style of management which is concerned with obtaining and managing resources to exploit an opportunity. The theory was useful to the study because HIV and AIDS workplace policy provides windows of opportunity that can be tapped in impact mitigation. Policy development, then, is a pattern of behaviour, a style of management which is concerned with obtaining and managing resources to exploit an opportunity. The fundamental thinking behind adopting the E-V- $\mathrm{R}$ model in this study is the premise that if examination on what public universities achieve strategically by making use of HIV and AIDS policies is done, then there should be a reduction on HIV impact at the workplace and an improved productivity amongst the workforce of Moi University. It is widely acknowledged that public universities are not confined to any one type of educational pursuit. Moreover, there are several types of education programs. Some build education out of creativity, invariably with determination and effort. One key challenge for all education institutions is dealing with HIV and AIDS which is bound to affect the strategic and structural changes required for growth. Some administrators cannot manage this pandemic effectively and hence academic programmes lose direction and momentum, whilst others are able to change their style appropriately (Thompson et al., 2000). The E-V-R congruence model was identified as a theoretical model that could provide insight on HIV and AIDS policy in the response to HIV and AIDS mitigation at Moi University.

\section{Methods}

Moi University was chosen because it was considered as rich of information sought in the study. Reports from the Human resources department of Moi University revealed low level of awareness about HIV/AIDS workplace policy awareness. The study, whose main concern was about Moi University HIV and AIDS workplace policy, targeted teaching staff, non-teaching staff and senior management. To achieve this objective, the study used ex-post facto research design and stratified sampling technique in the selection of the study sample. A study sample made up of 330 participants was used for the study. The study utilized both qualitative and quantitative methods in data collection. These included Workplace Testing Questionnaire, document analysis and semistructured interviews. Primary data was collected by use of self-administered questionnaires and interview schedules, while secondary data was collected from libraries. survey method of cross sectional type was used to collect data using a self-made five- point likert scale with the following response categories: Strongly Disagree $=1$; Disagree $=2$; Not Sure $=3$; Agree $=4$ and Strongly Agree $=5$. The study used the Statistical Package for Social Sciences (SPSS v 22.0) program to analyze the data collected. Qualitative data was analyzed thematically through coding. Both descriptive and inferential statistics were used. The descriptive statistics included frequencies and means. Correlation analysis was used to test hypotheses (to test the relationship between the independent and dependent variables).

International Journal of Educational
Studies
Vol. 2 , No.2, pp. $115-120$
2019
DOI: $10.53935 / 2641-533 x . v 2 i 2.113$
Funding: This study received no specific
financial support.
Article History:
Received: 8 May 2019
Revised: 12 June 2019
Accepted: 16 July 2019
Published: 29 August 2019
() 2019 by the authors; licensee Academic
Publishing Group
Publishing Group

\section{Results}

4.1. Determine the relationship between HIV and AIDS consultation and participants awareness on HIV and AIDS workplace policy development

A descriptive analysis was run to determine whether Moi University staff were consulted during HIV and AIDS policy development and also whether they were also aware of the existence of any HIV and AIDS policy. 


\section{HIV and AIDS Workplace Policy Consultation}

Table 1 presents participants' responses on whether or not participants were consulted during the Moi University HIV and AIDS staff workplace policy development.

Table-1. Not Consulted on HIV and AIDS Policy Development

\begin{tabular}{lll}
\hline Response & Frequency & Percent \\
\hline Strongly disagree & 69 & 20.9 \\
Disagree & 49 & 14.8 \\
Not sure & 71 & 21.5 \\
Agree & 74 & 22.4 \\
Strongly agree & 41 & 12.4 \\
No Response & 26 & 8 \\
Total & $\mathbf{3 3 0}$ & $\mathbf{1 0 0}$ \\
\hline
\end{tabular}

According Table 1, a total of $20.9 \%$ and $14.8 \%$ of the participants strongly disagreed and disagreed respectively with the statement that they were not consulted during the development of the Moi University HIV and AIDS workplace policy. On the other hand, $22.4 \%$ and $12.4 \%$ of the participants agreed and strongly agreed respectively with the statement that they were not consulted on HIV and AIDS workplace policy development while $22.4 \%$ of the respondents were not sure of what to say.

From the analysis, it was evident that a total of $34.8 \%$ of the participants did not participate in giving their views about HIV and AIDS workplace policy development, compared $35.7 \%$ of those consulted and $21.5 \%$ who were not sure.

The extent to which participants were aware on the existence of HIV and AIDS workplace policy at Moi University

Table-2. Moi University HIV and AIDS Workplace Policy

\begin{tabular}{lll}
\hline Response & Frequency & Percent \\
\hline Strongly disagree & 91 & 27.6 \\
Disagree & 68 & 20.6 \\
Not sure & 68 & 20.6 \\
Agree & 58 & 17.6 \\
Strongly agree & 19 & 5.8 \\
No Response & 26 & 7.9 \\
Total & $\mathbf{3 3 0}$ & $\mathbf{1 0 0}$ \\
\hline
\end{tabular}

Table 2 shows that $17.6 \%$ of the participants agreed that Moi University had an HIV and AIDS policy whilst $20.6 \%$ of the participants were not sure and $27.6 \%$ of the participants strongly disagreed with the statement that Moi University had an HIV policy. The percentage of those who agreed or strongly agreed, it is evident that $36 \%$ of the total participants indicated that Moi University had an HIV and AIDS workplace policy while $30.7 \%$ of the total participants who either strongly disagreed or disagreed indicated that Moi University did not have an HIV and AIDS workplace policy.

The correlations among the staff of Moi University with regard to their awareness of the University HIV and AIDS workplace that 'there was no significant relationship between HIV and AIDS workplace policy awareness and consultation on HIV and AIDS policy development among the staff of Moi University revealed that, there was a positive but weak correlation between awareness on HIV Workplace policy and consultation $(\mathrm{r}=.102)$ on HIV and AIDS policy development. This analysis revealed that there was a significant positive relationship between nonteaching and teaching $(\mathrm{r}=1.00)$ non-teaching and senior management $(\mathrm{r}=.838)$, teaching and senior management (.837) on the awareness of HIV and AIDS workplace policy at Moi University. In view of the evidence from the analysis, the null hypothesis which stated that 'there is no significant

Internatios

Vol. 2, No.2, pp. 115-120

2019

$10.53935 / 2641-533 x . v 2 i 2.113$ Funding: This study received no specific financial support.

Received: 8 May 2019

Revised: 12 June 2019

Accepted: 16 July 2019

Published: 29 August 2019

(C) 2019 by the authors; licensee Academic Publishing Group 
relationship between HIV and AIDS workplace policy awareness and consultation on HIV and AIDS policy development among the staff of Moi University' was therefore rejected.

\section{Discussion}

International Labour Organization (ILO) (2001) underscores the significance of undertaking an organizational official launch of the policy as one way of marketing and popularizing the policy if this is not considered, then it can be an impediment to the successful HIV and AIDS workplace policy implementation.

It is important that all employees understand the content of the policy and what is expected from them. Senior management, members of staff, union representatives, and supervisors need to be aware and understand the HIV and AIDS workplace policy and their role in administering it. This can be done through: pamphlets, displaying the policy in public places, uploading the policy in the internal website, awareness and education sessions, undertaking an institutional official launch as a marketing platform with the support of the organization's chief Executive Officer. These will show some element of commitment and full support from senior management.

In 2000, Kwame Nkrumah National University of Science and Technology (KNUST) was the first University in Africa to establish the Health and Nutrition Coordinating Centre. The main objective was to educate through counselling and the mainstreaming of HIV and AIDS into KNUST curriculum, offer nutrition advice to people living with HIV and AIDS (PLWHA). The university developed a draft institutional policy and also provided for dispassionately disseminating information and dealing with the disease (Oti-Boateng et al., 2004). With full support of senior management, the university was able to reduce HIV and AIDS impact at the University. As part of its (KNUST's) core mandate of teaching, research and service to the community, the University is also engaged in activities that promote dissemination and preservation of knowledge regarding HIV transmission, and its impact on the university, the individual, the family and the community.

An HIV and AIDS workplace policy is a very important document which guides managers and supervisors on how to manage HIV and AIDS in a consistent manner and informs employees about their responsibilities, rights and expected behaviour (International Labour Organization (ILO), 2002). For a successful workplace programme of HIV and AIDS intervention, every employee has to be aware of the document and its content.

\section{Conclusion and Recommendations}

The study sought to determine the relationship between HIV and AIDS consultation and participants awareness on HIV and AIDS workplace policy development. Correlation analysis was used to test hypotheses (to test the relationship between the independent and dependent variables). The findings revealed that Moi University had an HIV and AIDS workplace policy. It also emerged that lack of consultation on HIV policy development, was an impediment to successful implementation of the policy. The study concluded that HIV and AIDS workplace policy is a vital document in HIV and AIDS impact mitigation and, therefore, requires serious consultation among all employees of Moi University for purposes of ownership by every employee. Following this, the study recommended that consultation of all of all employees about HIV and AIDS workplace policy development be undertaken and worker's views and opinion be considered when developing an HIV and AIDS workplace policy. The study is, therefore, expected to be of great significance to universities in addressing some of the HIV and AIDS workplace policy related awareness and consultation challenges.

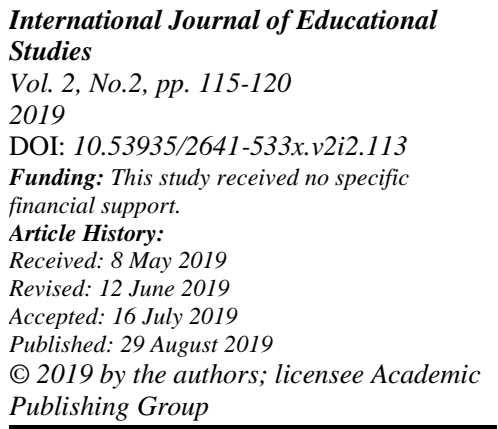

\section{References}

Carr-Hill, R., Kataboro, \& Katahoire, A. (2000). HIV/AIDS and education. Unpublished Draft Report by Institute of Development, University of Dar-es-Salaam and University of Makerere.

Education International. (2006). Training for life. Draft Report, Teacher Training on HIV/AIDS, EI, Brussels, May. International Labour Office. (2004). Workplace action on HIV/AIDS ILO Newsletter, (5), November. Geneva: ILO. International Labour Organization (ILO). (2001). ILO code of practice. Geneva: ILO.

International Labour Organization (ILO). (2002). Technical workshop on population mobility, migration, and HIV/AIDS, Geneva. Paper presented at the Meeting Report 3. 
Oti-Boateng, P. E., Owusu-Daaku, F., \& Yeboah, F. A. (2004). Awareness creation on HIV/AIDS. Paper presented at the Workshop at KNUST, Accra.

Phakathi, S. (2006). Literature review. In Vass, J. \& Phakathi, S. Managing HIV in the Workplace: Learning from SMEs. Cape Town Human Sciences Research Council.

Thompson, J. L., Lees, A., \& Alvy, G. (2000). Social entrepreneurship-a new look at the people and the potential. Management Decision, 38(5), 328-338.Available at: https://doi.org/10.1108/00251740010340517.

UNESCO. (2005). Towards an AIDS-free generation. Paris: For Global Campaign IIEP/UNESCO.

\author{
International Journal of Educational \\ Studies \\ Vol. 2, No.2, pp. 115-120 \\ 2019 \\ DOI: $10.53935 / 2641-533 x . v 2 i 2.113$ \\ Funding: This study received no specific \\ financial support. \\ Article History:
Received: 8 May 2019 \\ Received: 8 May 2019 \\ Accepted: 16 July 2019 \\ Published: 29 August 2019 \\ (c) 2019 by the authors; licensee Academic \\ Publishing Group
}

